Short communication

\title{
Fungal diversity of "Tomme d'Orchies" cheese during the ripening process as revealed by a metagenomic study
}

\author{
Alexandre Ceugniez $^{\mathrm{a}}$, Bernard Taminiau ${ }^{\mathrm{b}}$, Françoise Coucheney ${ }^{\mathrm{a}}$, Philippe Jacques ${ }^{\mathrm{a}}$, \\ Véronique Delcenserie ${ }^{\mathrm{b}}$, Georges Daube ${ }^{\mathrm{b}}$, Djamel Drider $^{\mathrm{a}, *}$ \\ ${ }^{a}$ Univ. Lille, INRA, Univ. Artois, Univ. Littoral Côte d'Opale, EA 7394 - ICV - Institut Charles Viollette, F-59000 Lille, France \\ ${ }^{\mathrm{b}}$ Fundamental and Applied Research for Animal \& Health (FARAH), Food Science Department, Faculty of Veterinary Medicine, University of Liège, Liège B-4000, Belgium
}

\section{A R T I C L E I N F O}

\section{Keywords:}

Artisanal cheese

Illumina

5.8S-ITS2 rDNA

Fungal microbiota

\begin{abstract}
A B S T R A C T
Tomme d'Orchies is an artisanal pressed and uncooked cheese produced and marketed in the north of France. This study aimed at showing the fungal microbiota evolution of this cheese using a metagenetic based Illumina technology targeting the ITS2 domain of 5.8S fungal rDNAs. To this end, samples were taken from the rind and the core of different cheeses, after $0,1,3,7,14$ and 21 days of ripening. The data underpinned the prevalence of Yarrowia lipolytica and Galactomyces geotrichum for both microbiotas. Unusual species including Clavispora lusitaniae, Kazachstania unispora and Cladosporium cladosporioides were also detected, but their origins remain to be ascertained. The metagenomic revealed also the presence of Kluyveromyces and Debaryomyces species.
\end{abstract}

\section{Introduction}

Advances in genomic and metagenomic sequencing are providing researchers and industrialists with insightful informations on the bacterial, fungal and viral diversities in many traditionally produced foods. DNA sequencing based technologies applied for different habitats provided a snapshot of the microbial diversity within and across environments (Lozupone and Knight, 2007). Large differences from one environment to another one were reported, and the number of species occupying such niches can reach hundreds even thousands (Lozupone and Knight, 2007). Complex ecosystems are not easy to rebuild in vitro because of the non-cultivable hallmark of some species (Wolfe and Dutton, 2015). This drawback avoids therefore to understand the role of each species. Cheese microbiota is a complex ecosystem contributing tightly for cheese flavor, aroma, texture, and appearance (Beresford et al., 2001; Irlinger and Mounier, 2009; Ogier et al., 2002). Fungal species found in cheese are known to exert positive effects, but some species as Penicillium commune (Lavoie et al., 2012), or Debaryomyces hansenii at high concentration (Fleet, 2011) could be deleterious. These microorganisms are thought to be issued from raw milk, and other sources as the environment of production and ripening (Atanassova et al., 2016; Wojtatowicz et al., 2001). Interestingly, Wolfe et al. (2014) sequenced 137 different rind microbiotas from 10 countries, and concluded that at least $60 \%$ of the bacterial, and $25 \%$ of the fungal communities were other than the starter cultures.

Studies of fungal communities based on the amplification and sequencing of the ITS1-5.8S-ITS2 regions are suitable and adequate for the next generation sequencing methods, or NGS (Schoch et al., 2012). The 5.8S rDNA is highly conserved and could permit accurate taxonomic information, conversely to the ITS1 and ITS2 regions, which are highly variable give the species status (Lindahl et al., 2013). The NGS Illumina sequencing allow high throughput sequencing of total DNA without any prior culture, and provide therefore data on the viable-butnot-cultivable strains (Bokulich and Mills, 2012). The NGS Illumina technology is anticipated to evolve and become likely a routinely used method because of its swiftness and ease of utilization (Delcenserie et al., 2014; Franzosa et al., 2015). This technology leads to DNA fragments of about 35 to $150 \mathrm{bp}$, which are smaller than those reported for the ITS1-5.8S-ITS2 rDNA; an approach tightly recommended for yeast and fungi identifications (Schoch et al., 2012). According to Lindahl et al. (2013), the sequencing of the ITS2 domain could be used for fungal communities identification. Notably, the ITS2 region is smaller than the ITS1 domain, allowing more compatibility with Illumina technology.

The "Tomme d'Orchies" is a French artisanal cheese manufactured and marketed in the North of the country for less than 50 years. This uncooked pressed cheese, which is washed twice during ripening, is made with a local raw milk of Holstein cows. The use of a culturedependent approach (Ceugniez et al., 2015), and a metagenomic technology (Ceugniez et al., 2016) permitted to draw the first yeast and bacterial snapshots. Besides, the aforementioned reports portrayed some unusual bacterial species, and yeasts with beneficial properties.

\footnotetext{
* Corresponding author.

E-mail address: djamel.drider@univ-lille1.fr (D. Drider).
} 
Table 1

Fungal microbiota distribution, at the species level, in the core of the "Tomme d'Orchies" cheese, according to the period of ripening. Grey shading correspond to strain added as starter. Bold writing were molds, fine writing were yeasts.

\begin{tabular}{|c|c|c|c|c|c|c|c|c|}
\hline \multirow[b]{2}{*}{ OTU } & & \multirow[b]{2}{*}{0} & \multicolumn{3}{|c|}{ Ripening (Day) } & \multirow[b]{2}{*}{14} & \multirow[b]{2}{*}{21} & \multirow{2}{*}{ Average } \\
\hline & & & 1 & 3 & 7 & & & \\
\hline Yarrowia & lipolytica & $74.75 \%$ & $72.92 \%$ & $85.18 \%$ & $85.03 \%$ & $89.67 \%$ & $86.42 \%$ & $83.33 \%$ \\
\hline Galactomyces & geotrichum & $24.04 \%$ & $26.36 \%$ & $13.96 \%$ & $14.31 \%$ & $9.32 \%$ & $13.12 \%$ & $16.85 \%$ \\
\hline Saccharomyces & cerevisiae & $0.25 \%$ & $0.23 \%$ & $0.10 \%$ & $0.14 \%$ & $0.08 \%$ & $0.08 \%$ & $0.15 \%$ \\
\hline Aspergillus & niger & $0.10 \%$ & $0.16 \%$ & $0.12 \%$ & $0.08 \%$ & $0.10 \%$ & $0.06 \%$ & $0.11 \%$ \\
\hline \multirow[t]{2}{*}{ Cryptococcus } & sp. & $0.08 \%$ & $0.02 \%$ & $0.08 \%$ & $0.12 \%$ & $0.17 \%$ & $0.12 \%$ & $0.10 \%$ \\
\hline & curvatus & - & - & - & - & $0.02 \%$ & $0.02 \%$ & $0.01 \%$ \\
\hline Kazachstania & unispora & $0.23 \%$ & $0.04 \%$ & $0.08 \%$ & - & $0.10 \%$ & $0.02 \%$ & $0.08 \%$ \\
\hline \multirow[t]{3}{*}{ Candida } & rugosa & $0.13 \%$ & - & $0.04 \%$ & $0.02 \%$ & $0.12 \%$ & $0.02 \%$ & $0,06 \%$ \\
\hline & intermedia & - & - & $0.02 \%$ & $0.06 \%$ & $0.08 \%$ & $0.02 \%$ & $0,03 \%$ \\
\hline & parapsilosis & - & - & - & - & $0.02 \%$ & - & $<0.01 \%$ \\
\hline Debaryomyces & hansenii & $0.08 \%$ & $0.06 \%$ & $0.04 \%$ & $0.02 \%$ & $0.04 \%$ & $0.02 \%$ & $0.05 \%$ \\
\hline Kluyveromyces & marxianus & $0.04 \%$ & $0.02 \%$ & $0.06 \%$ & $0.04 \%$ & $0.06 \%$ & $0.04 \%$ & $0,05 \%$ \\
\hline Torulaspora & delbrueckii & $0.02 \%$ & $0.06 \%$ & $0.02 \%$ & $0.06 \%$ & $0.02 \%$ & - & $0,03 \%$ \\
\hline \multirow[t]{3}{*}{ Trichosporon } & sp. & $0.06 \%$ & $0.04 \%$ & - & - & $0.06 \%$ & - & $0.03 \%$ \\
\hline & ovoides & $0.02 \%$ & - & $0.06 \%$ & $0.02 \%$ & - & - & $0.02 \%$ \\
\hline & montevideense & - & - & $0.02 \%$ & - & $0.04 \%$ & - & $0.01 \%$ \\
\hline Pichia & fermentans & $0.04 \%$ & - & $0.06 \%$ & - & $0.02 \%$ & $0.02 \%$ & $0,02 \%$ \\
\hline Lewia & infectoria & $0.02 \%$ & $0.02 \%$ & $0.04 \%$ & - & $0.02 \%$ & - & $0,02 \%$ \\
\hline Clavispora & lusitaniae & $0.02 \%$ & - & $0.02 \%$ & - & - & $0.02 \%$ & $0,01 \%$ \\
\hline Cladosporium & cladosporioides & $0.02 \%$ & - & - & $0.02 \%$ & - & - & $0,01 \%$ \\
\hline Myrothecium & sp. & - & $0.02 \%$ & - & - & - & - & $<0.01 \%$ \\
\hline Nectria & sp. & - & - & $0.02 \%$ & - & - & - & $<0.01 \%$ \\
\hline Unidentified & & $0.08 \%$ & $0.04 \%$ & $0.06 \%$ & $0.04 \%$ & $0.06 \%$ & - & $0.05 \%$ \\
\hline
\end{tabular}

To gain more insights on the fungal microbiota, we analyzed samples withdrawn from different cheeses along ripening, and drawn a comprehensive overview on yeast and mold diversities of "Tomme d'Orchies" cheese.

\section{Materials and methods}

\subsection{Cheese manufacturing and sampling}

Tomme d'Orchies cheese was obtained from "G.A.E.C de la Motte" farm, located in Nomain (north of France). Cheese samples used here served as well to establish the bacterial metagenomic analysis (Ceugniez et al., 2016). Notably, D. hansenii PAL DH D purchased from Standa laboratories (Caen, France) was the only yeast employed as starter. To follow fungal diversity evolution along ripening, six different cheeses were sampled at $0,1,3,7,14$ and 21 days. One sample was taken from each cheese, and each cheese corresponds to one time of ripening. Afterwards, each sample was divided into rind and core before analysis, without replicates.

\subsection{DNA extraction and purification}

Cheese samples were centrifuged $\left(5000 \mathrm{~g}, 10 \mathrm{~min}, 4^{\circ} \mathrm{C}\right)$, and the resulting pellets were treated for $1 \mathrm{~h}$ at $37^{\circ} \mathrm{C}$ with a lysing buffer containing Tris- $\mathrm{HCl}(20 \mathrm{mM})$, EDTA (2 mM), Triton X-100 (1.2\%) and lysozyme $(20 \mathrm{~g} / \mathrm{L})$. Total DNA was extracted from each primary suspension with the DNeasy Blood \& Tissue DNA extraction kit (Qiagen, Venlo, the Netherlands), using the manufacturer's recommendations. Total DNA was then eluted into DNAse/RNAse-free water and quantified with a NanoDrop ND-1000 spectrophotometer (Isogen, St-Pieters-
Leeuw, Belgium). Pure DNA samples were stored at $-20{ }^{\circ} \mathrm{C}$ until to be used for 5.8S-ITS2 rDNA sequencing.

\subsection{8S-ITS2 rDNA gene library construction and sequencing}

The 5.8S-ITS2 rDNA PCR libraries were prepared for each cheese sample using universal primers with Illumina overhand adapters targeting the ITS2 region. The forward primer ITS3KYO2 (5'GATGAAGAACGYAGYRAA- $3^{\prime}$ ), and the reverse primer ITS4 (5'TCCTCCGCTTATTGATATGC-3') were used for their high coverage of fungi taxon (Toju et al., 2012). Each PCR product was purified with the Agencourt AMPure XP beads kit (Beckman Coulter, Pasadena, USA). A second indexing PCR was performed with the Nextera XT index primers 1 and 2 (Illumina, San Diego, USA). The PCR products were purified as indicated above. Quantifications were made with the Quant-IT PicoGreen (ThermoFisher Scientific, Waltham, USA). To constitute a library, each PCR product, after quantification, was diluted to $10 \mathrm{ng} / \mu \mathrm{L}$ with Tris $10 \mathrm{mM}$ Tween $200.05 \%$ and all PCR products were mixed together. A 1\% agarose gel permitted to check, if the library was free of unwanted bands, if not, a new purification was performed with AMPure XP beads. A precise quantification, by $\mathrm{qPCR}$, of each sample in the library was performed using the KAPA SYBR ${ }^{\circledR}$ FAST qPCR Kit (KapaBiosystems, Wilmington, USA) before normalization, pooling and sequencing on a MiSeq sequencer using v3 reagents (Illumina, USA).

\subsection{Bioinformatics analysis}

Sequence reads processing were used as reported by Rodriguez et al. (2015) using MOTHUR software package v1.35 (Schloss et al., 2009), and UCHIME algorithm (http://drive5.com/usearch/manual/uchime_ 
Table 2

Fungal microbiota distribution, at the species level, on the rind of the "Tomme d'Orchies" cheese, according to the period of ripening. Grey shading correspond to strain added as starter. Bold writing were molds, fine writing were yeasts.

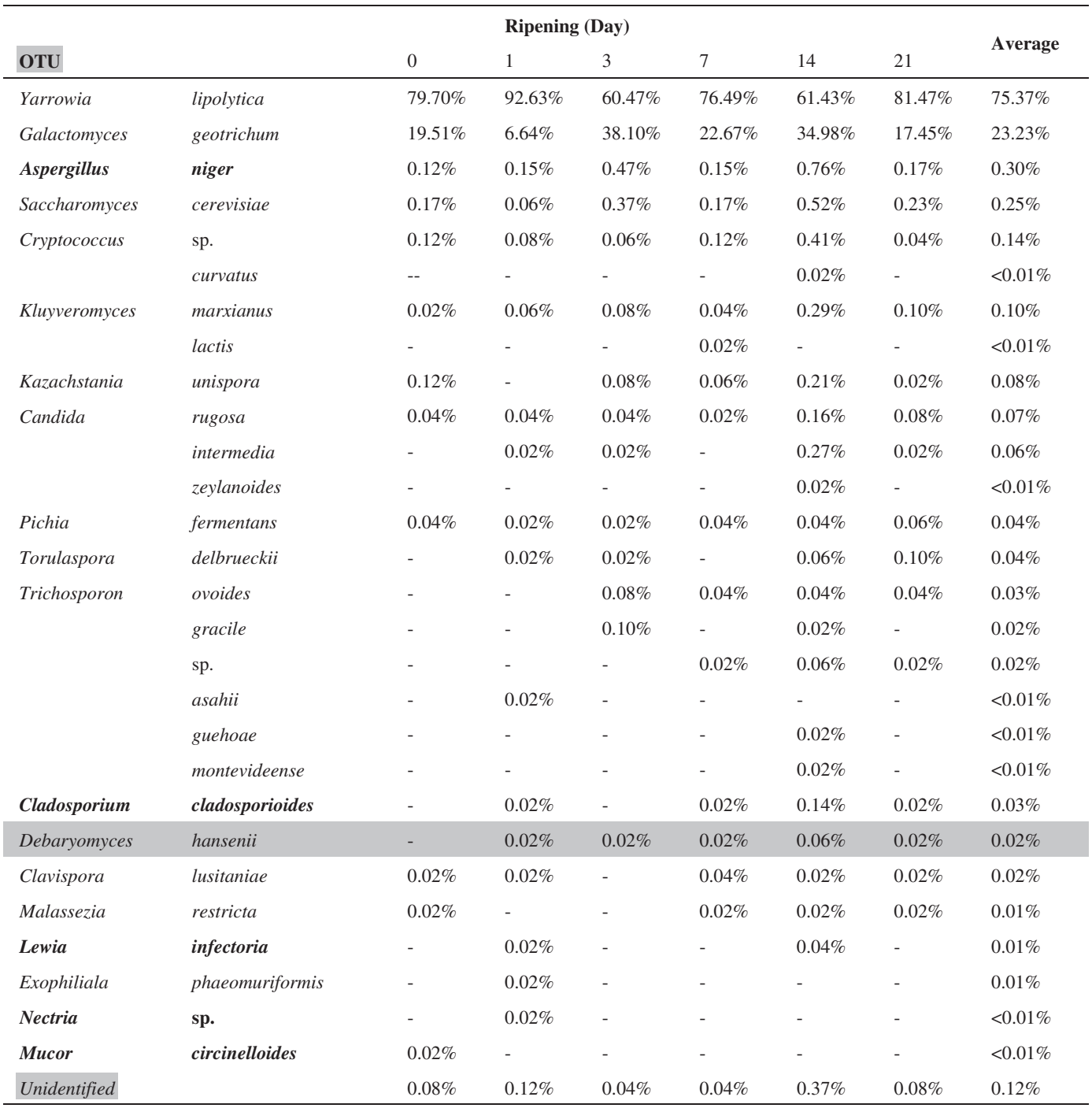

algo.html). The clustering distance for operational taxonomic unit (OTU) is 0.03. ITS2-5.8S rDNA reference alignment, and taxonomical assignation were based upon the UNITE database v6 (Kõljalg et al., 2013) of full-length ITS1-5.8S-ITS2 rDNA sequences, with an average length of $351 \mathrm{bp}$. All the biosample raw reads were deposited at the National Center for Biotechnology Information (NCBI) and now available under the Bioproject ID PRJNA355071.

\section{Results}

\subsection{Global cheese content}

The metagenetic study underpinned fungal OTUs encompassing family, genera and species taxonomic levels. A total of 30 OTUs containing 4 genera and 26 species were observed for this cheese. Molds were composed of 2 genera and 4 species. Notably, $0.05 \%$ of the sequences obtained from the core, and $0.12 \%$ from the rind were not identified (Tables 1 and 2).

\subsection{Core content}

The core of this cheese appeared to be dominated by Yarrowia lipolytica and Galactomyces geotrichum. At the beginning of the ripening (day 0), we noted that $74.75 \%$ of the sequences were allocated to $Y$. lipolytica, afterwards these sequenced had increased to $86.42 \%$, after 21 days of ripening (Table 1). On the other hand, G. geotrichum was present at $24.04 \%$ at the beginning of ripening before decreasing to $13.12 \%$, at the end of the process. These two species represent noteworthy $98.79 \%$ to $99.55 \%$ of the total sequences allocated for the fungal content. The sequences corresponding to the starter $D$. hansenii were ranging from $0.08 \%$ (at the beginning) to $0.02 \%$ (at the end) of the repining. The unidentified sequences were present at $0.08 \%$ at the beginning of the ripening before disappearing at the end of the ripening (Table 1). The core contains specific OTUs fitting with Candida parapsilosis and Myrothecium sp. Thus, we noticed 5 genera, including Aspergillus, Lewia (also known as Alternaria), Cladosporium, Myrothecium and Nectria. Notably, Aspergillus niger resulted to be the upmost prevalent species.

\subsection{Rind content}

$Y$. lipolytica and $G$. geotrichum species were also prevalent in the rind. The sequences allocated to $Y$. lipolytica ranged from $79.70 \%$ (at the beginning) to $81.47 \%$ (at the end) of the ripening (Table 2), while 
sequences of $G$. geotrichum remained stable along ripening. Indeed, at the beginning, G. geotrichum sequences were estimated to $19.51 \%$, and decreased slightly to $17.45 \%$ at the end of ripening (Table 2). Similarly, these two species are also prevalent in the rind and represent $99.21 \%$ of total sequences at the beginning, and decreased slightly to $98.92 \%$ at the end of the ripening. Specific OTUs corresponding to Candida zeylanoides, Exophiala phaeomuriformis, Kluyveromyces lactis, Malassezia restricta, Trichosporon asahii, T. gracile, T. guehoae and Mucor circinelloides were also evidenced here. Furthermore, sequences allocated to starter $D$. hansenii were estimated to $0.1 \%$. The rind microbiota appeared to be dominated by $Y$. lipolytica, $G$. geotrichum species, and at a lesser extent $D$. hansenii. Moreover, 18 different OTUs were evidenced. In this case, each OTU contained more than $0.01 \%$ of the total sequences. Therefore, the sequences resulting from these additional 18 OTUs were estimated to $0.743 \%$, (at the beginning) and $1.08 \%$, at the end of the ripening. Nevertheless, a peak of $3.13 \%$ of the sequences was observed after 14 days of ripening.

Molds potentially present in rind microbiota include the following genera: Aspergillus, Cladosporium, Lewia, Nectria, and Mucor. The most abundant species were $A$. niger and Cladosporium cladosporioides.

In the rind, we detected $0.08 \%$ of total sequences without any allocation. These non-identified sequences were remained overall stable along ripening of cheese (Table 2).

\section{Discussion}

Recently, we established the yeast diversity of "Tomme d'Orchies" using a culture-dependent approach (Ceugniez et al., 2015), to gain more insights on the fungal microbiota of this cheese, we carried out a metagenomic study based on the Illumina technology. Nevertheless these approaches were not fully concordant. While these methods permitted accurate identification of Clavispora lusitaniae, D. hansenii, Kluyveromyces marxianus, $K$. lactis and $Y$. lipolytica, the culture-dependent approach, but not the metagenetic one, allowed adventitious identification of Saturnispora mendoncae. This discrepancy could be explained by the absence of ITS2-5.8S rDNA sequences in the UNITE database matching with this species. On the other hand, the metagenetic technology permitted identification of a large panel of species including Candida intermedia, C. parapsilosis, C. rugosa, C. zeylanoides, Cryptococcus curvatus, E. phaeomuriformis, G. geotrichum, Kazachstania unispora, M. restricta, Pichia fermentans, Saccharomyces cerevisiae, T. asahii, T. gracile, T. guehoae, T. montevideense, T. ovoides and Torulaspora delbrueckii. The Illumina based metagenomic approach permitted to identify A. niger, C. cladosporioides, M. circinelloides, L. infectoria, Myrothecium sp., and Nectria sp.

In this analysis, we noticed the presence of Malassezia; a species which usually is isolated from human skin. Delavenne et al. (2011) underpinned the adventitious presence of $M$. restricta species in cow's and ewe's milk, while Guého-Kellermann et al. (2011) designed the manufacturer's skin as the main source. To the best of our knowledge, this is the first report underlining the presence of this fungal species in an artisanal cheese.

The culture-dependent approach recently conducted, and the current metagenetic analysis permitted to detect $Y$. lipolytica at a high proportion. The presence of this species in cheese is thought to be mediated in some strains by galactose and broadly by lactic acid (Kurtzman, 2011). Y. lipolytica has been reported as an emerging opportunistic pathogen specifically when afflicting immunodeficient patients (Jacques and Casaregola, 2008).

In turn, G. geotrichum might be originated from raw cow milk, as previously reported (Boutrou et al., 2006). Regarding D. hansenii, we noticed a weak proportion in "Tomme d'Orchies" along ripening, in contrary to Banjara et al. (2015) who indicated its prevalence in different cheeses.

A low fungal presence, with more than $0.11 \%$ of the total sequences, was registered for $S$. cerevisiae, A. niger and Cryptococcus sp. (Tables 1 and 2). Usually rinds are composed of a body of bacterial and fungal species issued from raw milk, starter cultures added by the cheesemakers, the aging environment, and likely other unknown sources (Fox et al., 2004; Quigley et al., 2013). The presence of $S$. cerevisiae in the rind could be explained by the rubbing of this cheese in a mix of brown beer. Nevertheless, the presence of Cryptococcus is not unusual as this species was reported as key species in the surface-ripened cheese (Corsetti et al., 2001), and other dairy products (Jakobsen and Narvhus, 1996; Lopandic et al., 2006). The low levels of both $K$. marxianus and $K$. lactis was noticed in previous studies (Delavenne et al., 2011; Cocolin et al., 2002). Other identified OTUs were detected at under $0.02 \%$ and $1.9 \%$ in the rind and in the core, respectively. The unusual cheese contaminant C. lusitaniae (Jacques and Casaregola, 2008; Jakobsen and Narvhus, 1996) was also found here. On the other hand, C. rugosa, $P$. fermentans and T. delbrueckii were found in raw milk (Cocolin et al., 2002; Delavenne et al., 2011; Fadda et al., 2004), whereas Trichosporon ovoides in human and animal sources (Fadda et al., 2004).

C. intermedia was found in different surface-ripening cheeses (Atanassova et al., 2016; Corsetti et al., 2001; Jacques and Casaregola, 2008), and was also reported as a contaminant of artisanal products (Lachance et al., 2011). Finally, Kazachstania unispora which is an unusual species, was encountered in fermented mare milk, semi-hard cow's milk, and other cheeses (Lopandic et al., 2006; Vaughan-Martini et al., 2011).

To sum-up, the "Tomme d'Orchies" possesses a fungal diversity quite similar to the previously reported for semi-soft cheeses (Corbo et al., 2001; Corsetti et al., 2001; Lopandic et al., 2006; Minervini et al., 2001). However the "Tomme d'Orchies" cheese contains some usual species at proportions that are usually different from other cheeses (data not shown). Notably for Y. lipolytica and G. geotrichum, resulted to be the most abundant species in both core and rind parts of the cheese.

The Illumina technology targeting the ITS2-5.8S rDNA permitted us to gain insights on the fungal diversity of this artisanal cheese and show its capabilities to described fungal cheese microbiota. However, some adjustment in the database content was needed to be totally functional.

\section{Acknowledgements}

This work was supported by "Le Ministère de l'Enseignement Supérieur et de la Recherche, France" through PhD grant awarded to Alexandre Ceugniez. The authors would like to thank Mr. Antoine Jean, from the G.A.E.C de la Motte at Nomain (France) for providing samples used in this study, and Dr. Bruce Seal from Oregon State University (USA) for English improvement and critical reading of the manuscript.

\section{References}

Atanassova, M.R., Fernández-Otero, C., Rodríguez-Alonso, P., Fernández-No, I.C., Garabal, J.I., Centeno, J.A., 2016. Characterization of yeasts isolated from artisanal short-ripened cows' cheeses produced in Galicia (NW Spain). Food Microbiol. 53, 172-181. http://dx.doi.org/10.1016/j.fm.2015.09.012.

Banjara, N., Suhr, M.J., Hallen-Adams, H.E., 2015. Diversity of yeast and mold species from a variety of cheese types. Curr. Microbiol. 70, 792-800. http://dx.doi.org/10. 1007/s00284-015-0790-1.

Beresford, T.P., Fitzsimons, N.A., Brennan, N.L., Cogan, T.M., 2001. Recent advances in cheese microbiology. Int. Dairy J. 11, 259-274. http://dx.doi.org/10.1016/S09586946(01)00056-5.

Bokulich, N.A., Mills, D.A., 2012. Next-generation approaches to the microbial ecology of food fermentations. BMB Rep. 45, 377-389. http://dx.doi.org/10.5483/BMBRep. 2012.45.7.148.

Boutrou, R., Kerriou, L., Gassi, J.-Y., 2006. Contribution of Geotrichum candidum to the proteolysis of soft cheese. Int. Dairy J. 16, 775-783.

Ceugniez, A., Drider, D., Jacques, P., Coucheney, F., 2015. Yeast diversity in a traditional French cheese "Tomme d'Orchies" reveals infrequent and frequent species with associated benefits. Food Microbiol. 52, 177-184. http://dx.doi.org/10.1016/j.fm. 2015.08.001.

Ceugniez, A., Taminiau, B., Coucheney, F., Jacques, P., Delcenserie, V., Daube, G., Drider, D., 2016. Use of a metagenetic approach to monitor the bacterial microbiota of "Tomme d'Orchies" cheese during the ripening process. Int. J. Food Microbiol. http:// dx.doi.org/10.1016/j.ijfoodmicro.2016.10.034.

Cocolin, L., Aggio, D., Manzano, M., Cantoni, C., Comi, G., 2002. An application of PCR- 
DGGE analysis to profile the yeast populations in raw milk. Int. Dairy J. 12, 407-411. http://dx.doi.org/10.1016/S0958-6946(02)00023-7.

Corbo, M.R., Lanciotti, R., Albenzio, M., Sinigaglia, M., 2001. Occurrence and characterization of yeasts isolated from milks and dairy products of Apulia region. Int. J. Food Microbiol. 69, 147-152.

Corsetti, A., Rossi, J., Gobbetti, M., 2001. Interactions between yeasts and bacteria in the smear surface-ripened cheeses. Int. J. Food Microbiol. 69, 1-10. http://dx.doi.org/ 10.1016/S0168-1605(01)00567-0.

Delavenne, E., Mounier, J., Asmani, K., Jany, J.-L., Barbier, G., Le Blay, G., 2011. Fungal diversity in cow, goat and ewe milk. Int. J. Food Microbiol. 151, 247-251. http://dx. doi.org/10.1016/j.ijfoodmicro.2011.08.029.

Delcenserie, V., Taminiau, B., Delhalle, L., Nezer, C., Doyen, P., Crevecoeur, S., Roussey, D., Korsak, N., Daube, G., 2014. Microbiota characterization of a Belgian protected designation of origin cheese, Herve cheese, using metagenomic analysis. J. Dairy Sci. 97, 6046-6056. http://dx.doi.org/10.3168/jds.2014-8225.

Fadda, M., Mossa, V., Pisano, M., Deplano, M., Cosentino, S., 2004. Occurrence and characterization of yeasts isolated from artisanal Fiore Sardo cheese. Int. J. Food Microbiol. 95, 51-59. http://dx.doi.org/10.1016/j.ijfoodmicro.2004.02.001.

Fleet, G.H., 2011. Yeast spoilage of foods and beverages. In: Kurtzman, C.P., Fell, J.W., Boekhout, T. (Eds.), The Yeasts: A Taxonomic Study. Elsevier, Amsterdam, pp. 53-63.

Fox, P.F., McSweeney, P.L.H., Cogan, T.M., Guinee, T., 2004. Cheese: Chemistry, Physics and Microbiology. Elsevier Academic, Oxford.

Franzosa, E.A., Hsu, T., Sirota-Madi, A., Shafquat, A., Abu-Ali, G., Morgan, X.C., Huttenhower, C., 2015. Sequencing and beyond: integrating molecular "omics" for microbial community profiling. Nat. Rev. Microbiol. 13, 360-372. http://dx.doi.org/ 10.1038/nrmicro3451.

Guého-Kellermann, E., Batra, R., Boekhout, T., 2011. Malassezia Baillon (1889). In: Kurtzman, C.P., Fell, J.W., Boekhout, T. (Eds.), The Yeasts: A Taxonomic Study. Elsevier, Amsterdam, pp. 1807-1832.

Irlinger, F., Mounier, J., 2009. Microbial interactions in cheese: implications for cheese quality and safety. Curr. Opin. Biotechnol. 20, 142-148. http://dx.doi.org/10.1016/ j.copbio.2009.02.016.

Jacques, N., Casaregola, S., 2008. Safety assessment of dairy microorganisms: the hemiascomycetous yeasts. Int. J. Food Microbiol. 126, 321-326. http://dx.doi.org/10 1016/j.ijfoodmicro.2007.08.020.

Jakobsen, M., Narvhus, J., 1996. Yeasts and their possible beneficial and negative effects on the quality of dairy products. Int. Dairy J. 6, 755-768. http://dx.doi.org/10.1016/ 0958-6946(95)00071-2.

Kõljalg, U., Nilsson, R.H., Abarenkov, K., Tedersoo, L., Taylor, A.F.S., Bahram, M., Bates, S.T., Bruns, T.D., Bengtsson-Palme, J., Callaghan, T.M., Douglas, B., Drenkhan, T., Eberhardt, U., Dueñas, M., Grebenc, T., Griffith, G.W., Hartmann, M., Kirk, P.M., Kohout, P., Larsson, E., Lindahl, B.D., Lücking, R., Martín, M.P., Matheny, P.B., Nguyen, N.H., Niskanen, T., Oja, J., Peay, K.G., Peintner, U., Peterson, M., Põldmaa, K., Saag, L., Saar, I., Schüßler, A., Scott, J.A., Senés, C., Smith, M.E., Suija, A., Taylor, D.L., Telleria, M.T., Weiss, M., Larsson, K.-H., 2013. Towards a unified paradigm for sequence-based identification of fungi. Mol. Ecol. 22, 5271-5277. http://dx.doi.org/ $10.1111 / \mathrm{mec} .12481$.

Kurtzman, C.P., 2011. Yarrowia van der Walt \& von Arx (1980). In: Kurtzman, C.P., Fell, J.W., Boekhout, T. (Eds.), The Yeasts: A Taxonomic Study. Elsevier, Amsterdam, pp. 927-929.

Lachance, M.-A., Boekhout, T., Scorzetti, G., Fell, J.W., Kurtzman, C.P., 2011. Candida Berkhout (1923). In: Kurtzman, C.P., Fell, J.W., Boekhout, T. (Eds.), The Yeasts: A
Taxonomic Study. Elsevier, Amsterdam, pp. 987-1278.

Lavoie, K., Touchette, M., St-Gelais, D., Labrie, S., 2012. Characterization of the fungal microflora in raw milk and specialty cheeses of the province of Quebec. Dairy Sci. Technol. 92, 455-468. http://dx.doi.org/10.1007/s13594-011-0051-4.

Lindahl, B.D., Nilsson, R.H., Tedersoo, L., Abarenkov, K., Carlsen, T., Kjøller, R., Kõljalg, U., Pennanen, T., Rosendahl, S., Stenlid, J., Kauserud, H., 2013. Fungal community analysis by high-throughput sequencing of amplified markers - a user's guide. New Phytol. 199, 288-299. http://dx.doi.org/10.1111/nph.12243.

Lopandic, K., Zelger, S., Bánszky, L.K., Eliskases-Lechner, F., Prillinger, H., 2006. Identification of yeasts associated with milk products using traditional and molecular techniques. Food Microbiol. 23, 341-350. http://dx.doi.org/10.1016/j.fm.2005.05. 001.

Lozupone, C.A., Knight, R., 2007. Global patterns in bacterial diversity. Proc. Natl. Acad. Sci. 104, 11436-11440. http://dx.doi.org/10.1073/pnas.0611525104.

Minervini, F., Montagna, M.T., Spilotros, G., Monaci, L., Santacroce, M.P., Visconti, A., 2001. Survey on mycoflora of cow and buffalo dairy products from Southern Italy. Int. J. Food Microbiol. 69, 141-146.

Ogier, J.-C., Son, O., Gruss, A., Tailliez, P., Delacroix-Buchet, A., 2002. Identification of the bacterial microflora in dairy products by temporal temperature gradient gel electrophoresis. Appl. Environ. Microbiol. 68, 3691-3701.

Quigley, L., O'Sullivan, O., Stanton, C., Beresford, T.P., Ross, R.P., Fitzgerald, G.F., Cotter, P.D., 2013. The complex microbiota of raw milk. FEMS Microbiol. Rev. 37, 664-698. http://dx.doi.org/10.1111/1574-6976.12030.

Rodriguez, C., Taminiau, B., Brévers, B., Avesani, V., Van Broeck, J., Leroux, A., Gallot, M., Bruwier, A., Amory, H., Delmée, M., Daube, G., 2015. Faecal microbiota characterisation of horses using 16 rDNA barcoded pyrosequencing, and carriage rate of Clostridium difficile at hospital admission. BMC Microbiol. 15, 1. http://dx.doi.org/10. 1186/s12866-015-0514-5.

Schloss, P.D., Westcott, S.L., Ryabin, T., Hall, J.R., Hartmann, M., Hollister, E.B., Lesniewski, R.A., Oakley, B.B., Parks, D.H., Robinson, C.J., Sahl, J.W., Stres, B., Thallinger, G.G., Van Horn, D.J., Weber, C.F., 2009. Introducing mothur: opensource, platform-independent, community-supported software for describing and comparing microbial communities. Appl. Environ. Microbiol. 75, 7537-7541. http:// dx.doi.org/10.1128/AEM.01541-09.

Schoch, C.L., Seifert, K.A., Huhndorf, S., Robert, V., Spouge, J.L., Levesque, C.A., Chen, W., Bolchacova, E., Voigt, K., Crous, P.W., Fungal barcoding consortium, 2012. Nuclear ribosomal internal transcribed spacer (ITS) region as a universal DNA barcode marker for Fungi. Proc. Natl. Acad. Sci. 109, 6241-6246.

Toju, H., Tanabe, A.S., Yamamoto, S., Sato, H., 2012. High-coverage ITS primers for the DNA-based identification of ascomycetes and basidiomycetes in environmental samples. PLoS One 7, e40863. http://dx.doi.org/10.1371/journal.pone.0040863.

Vaughan-Martini, A., Lachance, M.-A., Kurtzman, C.P., 2011. Kazachstania Zubkova (1971). In: Kurtzman, C.P., Fell, J.W., Boekhout, T. (Eds.), The Yeasts: A Taxonomic Study. Elsevier, Amsterdam, pp. 439-470.

Wojtatowicz, M., Chrzanowska, J., Juszczyk, P., Skiba, A., Gdula, A., 2001. Identification and biochemical characteristics of yeast microflora of Rokpol cheese. Int. J. Food Microbiol. 69, 135-140. http://dx.doi.org/10.1016/S0168-1605(01)00582-7.

Wolfe, B.E., Dutton, R.J., 2015. Fermented foods as experimentally tractable microbial ecosystems. Cell 161, 49-55. http://dx.doi.org/10.1016/j.cell.2015.02.034.

Wolfe, B.E., Button, J.E., Santarelli, M., Dutton, R.J., 2014. Cheese rind communities provide tractable systems for in situ and in vitro studies of microbial diversity. Cell 158, 422-433. http://dx.doi.org/10.1016/j.cell.2014.05.041. 